\title{
Kirker i Sønderborg Provsti.
}

\section{Af Carsten Petersen.}

Først i nvere Tid er Als og Sundeved forenede til et Provsti. I forrige Tider har Sundeved hverken hort under Odense Bispestol eller været regnet til det senere Bispedømme Als-Arø. Der er derfor ingen Grund til at søge særlige fælles historiske Træk i disse Kirker. Det samme gælder om Kirkerne i Sønderborg og Kegnæs, som først er byggede af Hertug Hans d. y.

Jeg lader Grænsen mellem de gamle Kirkeprovinser gælde og begynder med Kirkerne i

\section{Sundeved.}

Det gamle Nybølherred omfattede Nybøl, Broager, Ullerup, Sottrup og Dybbøl Sogne. Tingstedet laa ved Nybøl Kirke. Ved daarligt Vejr gik Herredsfogeden og hans Bønder ind i Kirken. Men engang i Tiden flyttedes Tinget til Broager. Her ligger Kæmpen i Landskabet: Kirken med sit Dobbelttaarn. sine Korsfløje, sin Korrunding (Apsis) og sine Hvælvinger, stolt beherskende hele Halvøen. Undersøgelser fra den nyeste Tid har godtgjort, at Udsmykningen i det Indre endnu i Begyndelsen af den her omhandlede Tidsperiode, henimod 1550, har svaret til Bygningens Betydning. Helt i Slutningen af Middelalderen var der malet et Billede af Dommedagen, Middelalderens kære Forestilling, i Hovedhvælvingen og i den nordre Korsarm St. Georgs Martyrlegende. Den samme Ridder, kæmpende med Dragen, er nu opstillet i Taarnrummet. "At denne Gruppe har haft sin Plads i den nordre Korsarm er givet. Og hvilken Pragt har da ikke præget dette Sted i Kirken, hvor Vægmaleriernes rene og glødende Farver har spillet omkap med den ikke mindre farvestraalende Ryttergruppes. (E. Lind). I Slutningen af Aarhundredet maledes Evangelisterne i Korshvælvingen. 
Forøvrigt tier Regnskabsbøgerne om det 16. Aarhundrede. Men i Begyndelsen af det næste Aarh. er der bygget en Del. Baade Broager og Nybøl Kirker laante Penge tho ehrem gebuwete. Ullerup kom ogsaa i Fart. Nyt Loft lagdes 1610. Paa samme Tid en ny Døbefont. Kaplanen Hr. Jakob betalte vor dem olden Döbeketel 5 M. Hvad han vilde bruge den til, sagde han ikke. Den nye Daabssten kom mærkværdigvis fra Dybbøl Kirke. Videre skænkede Naadigherren (Hertugen) en Brudekrans af Sølv 1614. Nye Kvindestole er der 1617, Kalk og Disk lavet af Petter Buros i Flensborg 1618, en Skriftestol med 6 Knapper 1619 o. s. v.

Medens Glæden over Guds Hus i Ullerup maa være vokset Aar for Aar, ramtes Kirken i Nabosognet Sottrup af en stor U'lykke. Præsten beretter, at en Søndag mellem Jul og Paaske 1625 var der en stærk Storm af Sydvest, hvorved Taarnet blæste ned. Omtrent 1/a Time efter at Folk var gaaet ud af Kirken, styrtede Spiret og sønderslog Blytaget helt hon til Koret. Blandt andet fandt man en Bjælke i Hans Asmussens Toft $\tilde{j} 0$ Favne fra Taarnmuren, hvorover alle som saa det maatte forundre sig, og hvem der frygtede Gud kunde ikke se paa det uden Taarer. Hertug Filip tog det som en Guds Dom. Han og Broderen Aleksander havde nemlig haft Strid om Ejendomsretten til denne Kirke. Nu faldt Taarnet over paa Filips Jord. Han forstod Fingerpeget. byggede det op igen og vandt saaledes Retten. Stundom er det klogt og godt at vedkende sig Pligten, inden vi strides om Retten.

I Kejserkrigen plyndredes en Del Kirker. Der berettes, at det danske Krigsfolk, so Anno 1627 d. 15. Sept. by Holdenisfehr angestrandet und ganz Sundewitt uthgeplündert, so wal de Kercken alse de Karspellude (Sognefolkene) disser Kercken gerouet hefft.

En anden Ødelægger kom midt i Fredstiden. Det var den ærlige Jens Murmand, som kom ind i Ullerup Kirke med en Hvidtekost og 7 Tender Kalk, uden at ville noget ondt. Han oversmurte alle Kirkens Vægge. Hvad der var af Livets Far- 
ver, af Slægters Tro i gamle Legender og Bibelhistorie forsvandi som i en Grav, om der gives en Opstandelse ved vi ikke. Nogen Erstatning fik Menneskenes Øjne 1642, da et Par Malere fra Tønder lagde Farver paa Alter, Orgel, Prædikestol und sonsten. Forandringen maa have været stor.

Den store Lyst til Kirkeforskønnelse, som vi her var Vidue til, fik sit Grundskud i Svenskertiden. Ved Aar 1659 linser vi i Broager Regnskabsbog: "Her maa ikke forbigaaes i Tavshed, $i$ lıvor stor Nød og Forderv det hele Sundeved Land og i Sardeleshed Broager Sogn (der forhen stod som en skøn Lysthave) er hensat af Gud for vore Synders Skyld ved det fordærvelige Krigsvæsen i dette 58. og 59. Aar, saaledes at endog hele Hjem er uddøde for Hunger og Kummer, at af

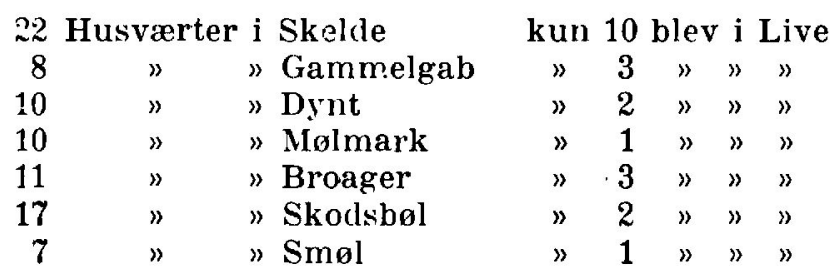

Saa kom i det 59. Aar foruden den store Dyrtid og Indkvartering af kejserlige, kongelige, polniske og kurbrandenburgske Folk ogsaa Blodgang blandt Beboeme og ifølge Indberetning cløde deraf i Sognet 225«. Derefter bemærkes 1660: "Hvad der nu er anført om dette Sogns Ruin, kan ogsaa siges om de øvrige Scgne i Sundeved (Nybøl undtaget) og deres Sognefolk, en Ødelæggelse, der minder om Profeten Amos Kap. 5,15: Maaske Herren den Sebaoths Gud maatte vorde det overblevne af Josef naadig ".

Da var det, at Markus Tinstøber i Flensborg lavede en Kalk og Flaske af Tin til Broager Kirke. Det burde have været Guld og Sølv. I Ullerup maatte Blytaget afbrydes paa Nordsiden og Pander kom i Stedet. Bjælkerne i Taarnet raadnede med Tiden, og man vidste ikke bedre Raad end at tage Spiret ned 1792. Endnu 1811 "solgtes gammelt Bly zum Dienst der Küstenmiliz. Der støbtes vel Kugler deraf. Hen i det 19. Aarh. blev Kirken 
»af en mærkelig Maler og Kunstner fra Varnæs meget pynteligt udmalet«. Det var vel ikke H. W. Eckersberg?

Broager Kirke solgte Kobber 1765, altid et Tegn paa Tilbagegang og Afkald. En Tagrytter forsvandt 1794. Men kritisk blev det for den store Kirke, da Dobbelttaarnet raabte om Hjælp. Da skrev Præsten (Dithmer) til Provst og Amtmand: "Ich habe bereits vor mehreren Jahren den Vorsehlag (dass der unnütze Doppelte hohe Turm abgenommen wird), gethan, der aber mit Widerwillen aufgenommen ward. Und doch wird dereinst der Turm abgebrochen werden mussen«. (1802). Præsten fik sit kloge Raad fort frem for Overkonsistoriet i Slesvig, som dog erklærede: "et muss bei einer Reparation sein Bewenden haben«. Og Taarnet staar endnu.

Krigene i det 19. Aarh. tog naturligvis paa Kirkerne i denne Lign. Provst Kr. Karstensen skildrer den udøvede Vandalisme i Dybbøl 1848-50. Orgelet blev aldeles ødelagt. Paa Alterbordet sad man og flikkede Sko. Maleriat i Alterbladet blev udskaaret og stjaalet. Moses- og Kristusfigurerne blev lemlæstede, Døre og Stolestader ødelagte og brændte. Bag paa Alteret skrev en Soldat:

Wer nach Schleswig-Holstein ist gewesen, der kennt die Sachen schon zu gut.

Man muss mit solchen Schweinen leben sich auch quälen bis aufs Blut.

Fra Skærtorsdag til Pinse 1849 var Kirken og Kirkegaarden i Sottrup besat af Tropper.

Nybøl Kirke benyttedes af Militæret under begge Krige, Dybbøl naturligvis ogsaa. Broager fik Krigsskaden godtgjort af den kong. Kasse 1852 med $492 \mathrm{M}$.

Under Krigen 1864 toges ogsaa Ullerup Kirke i Brug af Militæret. Den 22. April (efter Dybbøls Fald) sendte Præsten som Kirkeværge en Skrivelse til Div. General Frh. v. Winzingerode for at bede om Tilladelse til at sætte Kirken, som i Februar blev omdannet til Blokhus, og Kirkegaarden, som var indrettet til Skanse, tilbage i forrige Stand. 
Mellem Krigene foretog man større Restaureringer i Tidens Aand, ikke altid uden Tab. Da solgtes bl. a. den gamle Døbefont i Ullerup. Efter at den en Tid havde tjent som Blomsterpotte $\mathrm{i}$ en Have, vendte den tilbage til sit rette Sted. I Sottrup laa Granitfonten slængt hen under Taarntrappen, indtil forstaaende Mennesker hentede den ud af Skammekrogen. Ellers restaurerede man saa godt man havde Forstand til, f. Eks. i Nybøl 1856 og følgende Aar, i Dybbøl paa samme Tid.

Lad os nu, som vi plejer, tale lidt om Taarnene, nogle af dem har vi allerede hørt om.

Med Undtagelse af Broager har ingen af Sundeveds Kirker bevaret sit oprindelige Taarn. Om Dybbøl ved vi slet ikke, om der fandtes et Taarn, før det nuværende blev bygget. Et Rytterspir skal være bygget 1630. I 1857 blev det gamle Træblokkehus, som stod ved Østenden af Kirken lige op til Kirkegaardsmuren, nedrevet og et Taarn bygget. Gennem dette Taarn blev Indgangen lagt, idet man nedbrød Vaabenhuset. Tegningen leveredes af Stadsbygmester W'instrup - den kendte - i Flensborg. I ed Grundlægningen stødte man paa over 100 Hjerneskaller.

I Ullerup var der 1642 en Udgift das Dach zu öffnen, da der neu thurm itzo stehet. Det gaar herefter under Navnet set lille Taarn«, altsaa vel en Tagrytter. Paa Grund af Skrøbelighed blev det nedbrudt 1792. Et Klokketaarn af Træ opførtes - der siges ikke hvornaar? - af Tommer fra det nedbrudte Slot Filipsborg. Dette Taarn var omkring 1900 saa daarligt, at det svingede frem og tilbage under Klokkeringningen. Da byggede man det nuværende store Taarn.

Kirketaarnet i Sottrup var, som vi saa, blæst ned og genrejst 1625; men et Klokkehus maatte bygges 1666, fordi Taarnet var for svagt. Den 12. Sønd. e. Trin. 1687 ramtes selve Taarnet af Lynilden, uden at den tændte, og atter 1860 af et nyt Lyn, der tændte Flammer i den øverste Spids. Alle Slukningsforsøg var forgæves. Et nyt Taarn rejstes i samme Højde som det gamle cg staar endnu, kendeligt vidt omkring ved sin Slankhed og Højde. 
Om Nybøl kan siges det samme som om Dybbøl. Fra ældste Tid kendes intet Taarn. Vel siges der udtrykeligt, at Kirketaarnet blev nedbrudt 1830; men det drejede sig øjensynligt om et Rytterspir.

Broager er og bliver Taarnenes Br. Tvillingparret, som knejser uden Sidestykke i Sønderjylland, er saa gammelt, at vi ikke ved, hvornaar det er bygget. Men omkring 1650 var det stolte Bygningsværk saa svagt, at de tunge Klokker ikke kunde bevæges uden Fare. "Anno 1650" siger Regnskahet, "i Guds Navn og til hans FEre ogsaa til hele Sognets Bedste paa den durchlauchtige Fyrste og Herres (Hertug Filips') Befaling bygget et nyt Klokkehus, endsige da begge Taarne var saa svage, at den store Klokke deri vanskeligt kunde bruges«. Saa havde man altsaa 3 Taarne. Den gode Hertug Filip synes at have været en Taarnbygger. Han rejste Taarnet i Sottrup, lod bygge Taarnet $i$ Broager, og af hans Tømmer byggedes senere et Klokkehus $i$ Ullerup; om Klokkehuset i Nybol blev rejst paa hans Bud, er jkke oplyst. Men i Broager har der været endnu flere Taarne. Fn lille Klokke (Messeklokken) hang nemlig 1648 i ndet lille Klokketaarn«. Paa denne Tid havde altsaa Kirken i Broager 2 'Iaarne, et Rytterspir og et Klokkehus.

Sammenfattende kan siges, at Broager og Sottrup har haft Kirketaarne fra Middelalderen. Broager, Nybøl, Ullerup og Dybbøl har haft Rytterspir. Broager, Nybøl, Sottrup og Ullerup har haft Klokketaarne af Træ.

Paa Kirkegaardene i Broager og Dybbøl er der fundet en Mængde Dødningeben, som lader formodle, at gamle Benhuse er forsvundne.

I Kirkernes Indre maa vi endnu lade Blikket glide hen over det mangfoldige og skiftende Udstyr: Alter, Prædikestol, Orgel, Klokker o. s. v.

Altertavlen i Ullerup - schlecht und unbedeutend (Haupt) - er et Værk af Anton Günter Frese. Den tog Pladsen op efter en gammel fra det 16. Aarh., som gemmes endnu og anses for noget af det bedste $i$ Landet af den Slags Kunst. Oven over 
Alteret byggede man 1637 det store Orgel, som trængte til Hjælp 1811. Da endlich der Parcellist und Tischler Jürgen Markussen auf Lundsgaardfeld in hiesiger gemeinde wohnhaft, nunmehro mit der Allerh. Concession zur Treibung des Orgelbaues versehen worden, saa bad man om, at han maatte efterse Orglet.

Maaske var det den samme Maler - han kaldes Anton Günter Lundt i Sø̣nderborg og var Billedhugger - der leverede en Altertavle i Broager 1717. Den blev malet 1721 af Mons. Friedr. Welh. Petersen, Schilderer in Flensburg.

En Altertavle til Sottrup Kirke leveredes 1703 af den bekendte Billedskærer Peter Petersen i Tønder - kendt bl. a. fra Møgeltønder Kirke. Den blev sat istand og malet 1754 af en Maler fra Tønder. Men 1783 havde en hjemlig Snedker i Sottrup den Ere at skabe en ny Tavle, som blev malet af Jes Jessen. En Kvinde i Sognet dækkede Alteret med et smukt Klæde, hvorom der er skrevet: "Dette Alterklæde er syet af Jomfru Maria M. Wieden udi Sotrup og paalagt den 16. Okt. 1784: Jeg ønsker at enhver som skal nyde Jesu Christi sande Legeme og sande Blod ved dette hellige Alter, maatte erfare, at Jesu Christi Blod renser os af al Synd og at have Deel i Jesum er at være salig baade her og hisset.«

Ogsaa Altertavlen i Nybøl er malet af Jes Jessen (1804).

Iblandt Prædikestolene lægger vi Mærke til den i Ullerup, som bærer Aarstallet 1578. Den er smykket med smaa fikse Billeder af 4 Riddere skaarne i Træ, maaske Stolens Stiftere. Noget senere sattes Prædikestolen i Nybøl med sit prægtige Skjul (Lydhimmel). Mesteren, som skabte Stolen i Sottrup (1642) hed Klavs Gabriel og var en Kunstner paa Højde med Gudewert og Ringeling. Hans Stilretning, siges der, er overensstemmende med de danske Billedskærere og adskiller sig skarpt fra den tyske Barok. KKI. Gabriel var uddannet i København men levede i Flensborg.

Sundeved har tidligt elsket Musik. Provsten, Joh. Berndes skrev omkring 1570 til Præsten Peter Brun i Sottrup om en Degn, der kan spille Orgel - de ædituo idoneo et docto, qui or- 
ganis simul præesse possit. Han anbefaler Bern. Moller, som har været $\mathrm{i}$ den svenske Konges Kor og spillet forskellige Instrumenter. Joh. Berndes har selv hørt ham spille. Spørgsmaalet er, til hvilken Kirke denne Degn begæres. I Broager, hvor J. Berndes var Præst, fik man først senere et Orgel. Og da Anbefalingen er stilet til Sottrup, skulde man antage, at man der allerede paa det Tidspunkt havde Brug for en Organist.

Det første Orgel i Broager, som byggedes 1592, havde 6 Stemmer: Principal, Oktava, Mikstura, Mittelmæssig gedacht, Flöten, Regael. Præsten Knud Knudsen havde begyndt $\sin$ Lobebane som Sognets Degn. Men af en klottet Fole kan blive en Hest og af Knud Degn er blevet en Præst. Dog maatte han skaffe en kvalificeret og smuk Person, som kunde forestaa baade Kirken og Orgelet (1(i3i). Hr. Knud har da aabenbart indtil dette Tidspunkt udøvet Musikken.

Fra Nybøl har vi denne smukke Besked: "Eftersom den Høj Edle højærværdige og højlærde Mand Herr Joh. Dætri hans højfyrstl. Durchlauchtigheds til Glücksburg højtbetroede Hoffpredicand og Præpositus ud af en god Mening til Guds Fre og christelig Andacts Opmuntring har tilloudet voris samtl. Menighed at lade bygge et Orgawerk $i$ voris Kirke mens med saa skell ad Organisten for sin Møje aarligt skulde nyde 8 Rd. saa har vi samtykt (deri).... Skal Organisten derimod vere forplictet at spille paa Orgawerket effter Landsens Brug huer Søndag mens naar der falder Offer til Organisten, da søger hand sin stoel og annammer selff Offret som brugeligt er." Altsaa Offergangen skete uden Musik, det har nok været en tung Gang. Orgelet var ellers en Gave fra Hertugen 1720.

Kirkeklokken i Ullerup har en mærkelig Historie. Den stammer fra Nordstrand og var støbt omkring 1500. En Indskrift siger: A. 1629 alse ick hadde gehanget 122 Jhar, tho der Ehre Gottes gegeuen minen Klange, dho bin ick d. 4. Februar dorch vorwahrlosung der Soldaten mit fhur thoreten, de van der lidt hebben mi wedderuen laten geten dorch M. Peter Melchiorsen A. 1632. Men to Aar efter gik Sognet Lidt under i den 
store Flod. Klokken blev bjerget og blev $1640 \mathrm{k} ø b t$ til Ullerup Kirke. Kirkeværgen Nis Petersen drog afsted med Hest og V'ogn til Nordstrand og Husum sammen med Hr. Hansen. Det tog 9 Dage. Han blev enig med Folkene derude om at betale 800 M. for Klokken. Derefter sendtes 4 Personer med 8 Heste til Husum for at hente den over til Østkystens lave og smilende Bakker, der hænger den endnu.

\section{Als.}

Sejler man nordfra ind ad Alssund og lader Øjet glide hen over Ryggen af den smukke $\varnothing$ til venstre, standser Blikket af sig selv ved en Gruppe af høje Træer, der ved deres Fjernhed og rolige Linjer ikke virker paatrængende men dog gør sig gældende som en beherskende ubekendt Størrelse. Det er de himmelstræbende Lindetræer omkring Egen Kirke, plantede 1810. Af Bygningen er intet at se. Det er som om Kirken med sit lille Spir har dukket sig med Vilje for ikke at forstyrre Billedet. Er Navnet virkelig det samme som "Egene«, en Lund af gamle Kæmpeege fra V'ikingetiden eller saa, melder sig unægteligt Tanken om en Offerlund, en Helligdom af ældre Dato end Kirken, maaske et Tingsted tillige for hele Øen, et Madested for vaabenføre Mænd, Præster og Dommere. I senere Tid synes Egen virkeligt at have været Sæde for en alsisk Landsdommer, Tingsvidner fra 1502 og 1553 er udstedte paa Landstinget i Egen. De sad højt og saa langt disse Dommere, mod Nord og Syd, over Fjord og Sund. Mens Vinden suste gennem Egekronerne stemte de om Ret og Uret, Krig og Fred, Liv og Død. Endnu længe efter at Øen var delt $\mathbf{i}$ et Sønderog Nørreherred, faldt der stærke Domme paa Egen Herredsting. I Aarene 1633-34 drev en Bande omkring paa Als, ført af Hans Tater. De stjal i Egen Kirke 300 M. Kort efter blev de fangede, og seks af de skyldige mistede deres Liv paa Retterstedet uden for Kirken og lagdes paa Hjul og Stejle. Saadan ligger Historien omkring den for vort Blik usynlige Kirke. 
Engang gled Vikingebaadene maaske ind i Nærheden af de høje Ege, men nu gaar det ikke mere. Sejladsen gaar til Sønderborg og herfra spreder Vejene sig over Landet. Hver Kirke ligger ved en Gren af 'Alfarvejen, ofte staar dens Historie i Forbindelse netop med denne Vej. Vi faar Lejlighed til at lære noget af denne Historie, først vedrørende Kirkebygningen i Almindelighed.

Længst mod Nord ligger Nørborg. Her tiltraadte Præsten Hieronymus Eriksen sit Embede 1579 og begyndte straks at omkalfatre Kirken. Et nyt Loft blev bygget, hvorved der blev vundet 40 Mandsstole. Alteret stod under Hvælvingen som i en Bageovn (in einem backoven) og i Mørke, at han helt besværligt kunde læse Skriften. Han vilde ogsaa 1587 have smykket Alteret med en ny Tavle, som det var befalet i Synodalanordningerne (fra Odense?) og dertil var denne Plads bedst. Skriftestolen og Degnestolen har Præsten selv efter eget Tykke bygget saa stor og lille som han vilde uden nogen Indsigelse. Alle Stole lod han lave af nye. Men saadan kunde det ikke blive ved. En Dag blev Hr. Hieronymus Uvenner med Hertug Hans d. y. og det endte med Præstens Afskedigelse.

I Lysabild trak engang det hellige Blnds Kapel Pilgrimsskarer til sig, og Kirken havde i Middelalderen været rig, men da vore Regnskaber begynder, er det en fattig Kirke, som laaner Penge her og der og ikke har at betale Bygmesteren med. Den kostbare Monstrans med den hellige Hostie var horte ligesom Troen, der troede derpaa. Den siges at være ført »til Lunden i Skaane“ (Knudsen).

Endnu fattigere synes Kirken i Asserballe at have været. En af dens Præster har indberettet til sine Foresatte, hvad han vidste om dens Historie og dens Nød. Af visse Omstændigheder sluttede han, at en mægtig Mand, som efter Sagnet engang havde gæstet Als, maatte være Kardinal Joh. de Potentia, "som af Pafven blef sendt til Christian II". Af ham skulde der være givet Tilladelse til at bygge Kirken 1522 , som da blev kaldt $\mathrm{S}$. Clemens efter den daværende Pave. Dette kan næppe være rig- 
tigt. Kirken er ældre; men maaske var den oprindeligt kun et Kapel og blev først $\mathbf{i}$ det 16 . Aarh. til en Sognekirke. Den var saa lille, at den maatte gøres større ved Hjælp af Bidrag fra andre Sogne (1571). En lille Klokke havde den i sin Tid laant i Lysabild, som den nu fik Lov at beholde. Af sine smaa Midler havde den dog engang laant Jørgen Smyt 6 Gylden vor syn Ambolth myt anderem Smede tagge, havde altsaa hjulpet Byens Smed med at faa begyndt paa en Eksistens.

Fattigt maa det ogsaa have været i de Tider i Ulkebøl Sogn. Listen over Restanterne 1589 indeholdt bl. a.:

Jørgen Koches forarmet - intet at bekomme.

Jesper Hansen død og Børnene tigger.

Hans Nielsen, Manden død og Børnene tigger.

Jørgen Pedersen bleff hengd wid Nestwidt oc derfor intet at bekomme.

Jep Nielsen er dragen fra Gorden och forarmet.

Jørgen Kock er Rømbt for Tyfferi.

Jørgen Berteisen forarmed.

Mette Klavses forarmed.

Notmark Kirke nød godt af Thomas Sture og hans Hustru. Endnu da Præsten C. Knudsen arbejdede med sine Samlinger til Øens Historie fandtes paa Stolene dels ved Gangen, dels ved Væggen forskellige udskaarne Ansigter af Biskopper og Riddere, desuden Blomster o. a. Sture-Navnet og Aarstallet 1557 stod der ogsaa sammen med andre Adelsmænds Vaabenmærker, nogle malede i Hvælvingerne. Den smukke Udmaling, som nu er genfornyet, stammer fra 1564. Thomas Sture skal have ledsaget Krisitan II ind i Fangenskabet paa Sønderborg Slot. Han døde 1563, og et Mindesmærke over Agteparret er udhugget i Sandsten - 1569 do wort dit gemaket van Jacob van der Borck; det er lavet i Holland. Den gamle Altertavle var som den i Havnbjerg. Paa Loftet stod et stort jernbeslaaet Skrin, hvori Jomfru Marias Klædning gemtes.

Om Kejserkrigen og Torstenson-Fejden tier Kirkernes Bøger paa Als næsten helt. 
Anderledes med Svenskekrigen. Hr. Kristian Brandt, Præst i Nørborg, berettede om sin Kirkes Tilstand til Biskoppen i Odense 1672, "at voris St. Antonii Kirke allermest har udstaaet. Thi i den Nørborrigske Belejring, som den tid var, havde Polakkerne deres Ild i Kirken og opbrændte alle Stolene. Deres Heste førte de ogsaa derind, saa at sognefogeden imod den Søndag, paa hvilken man kunde holde Gudstjeneste der igjen, maatte rydde Hestemøget $u d, o g$ man maatte staaende bivaane Gudstjenesten. Gud lade os aldrig leve saadan Tid, men give os Fred i vore Dage for Christi Skyld«. Et hertugeligt Gravkapel byggedes 1687 .

Præsten Hans Gendtzmer i Tandslet klager over, "at han af de Brandenborgere blev berøvet fi0 $\mathrm{M}$ Kirkepenge, hvilke under Bigtstollen i Kirken med mere Kirkens tilhørige var nedersatt«. Kalk og Disk, skønt af Tin, gik ogsaa med Krigsfolket og kom ikke hjem igen. Anno 1690 fandtes endnu ingen Messehagel i Tandslet; thi den blev tilligemed Kalk og Disk (en Foræring af Fyrstinde Anna til Slesv.-Holst.) rovet i Fjendens Tid.

Samme Skæbne traf Kirken i Egen. 1658 hlev den "opbrudt med gewalt af de kejserlige, et helt vindue, hvor igjennem de stigede ind i Kirken, blev sønderbrudt og Alterets Ornatz tilligemed Messehagelen og en Sølvkalk m. a. bortranet af fornævnte Tropper«. Ny Sager maatte anskaffes.

Ogsaa Præsten i Asserballe (Chr. Müller 1690), som vì nævnte for lidt siden, saa Følgerne af Fjendetiden og raadede Bod derpaa saa godt han kunde. "Den ene Gaul." siger han, "paa Kirken bag Alteret, som heldte ud, hafuer ieg paa egen bekostning ladet giøre med Igebjelker og ladet Kirken inden oc uden kalke (da forsvandt altsaa alt hvad der var malet paa Væggene). I lige Maade ladet befæstige Klockhuset, som stod paa fald oc ladet et Pulpitur bygge i Kirken. Min Kirke formaar intet, men schal hielpis af andre». Den hvide Farve synes Kirken allerede at have haft $\mathrm{i}$ det Ydre hundrede Aar før. Aar 1589 
skal den nemlig mantælis oc Dønnickis uden paa, d. e. afpudses og hvidtes (sl. Tønder Provsti).

Hvordan man anstrengte sig for at erstatte Tabene, ser man f. Eks. i Ketting. Forvalteren paa Gammelgaard forærede 1658 - saa hurtigt! - en ny Kalk til Ketting Kirke, »der de wmilde Krigs-Folk, Kejserlige, Brandenborgere och Polakker -- de var alle lige gode - berøfued Kirkerne och ded gandsche Land. Gud erstatte hannem denne Velgierning mod Guds Huus hunderfold. Och lade i sin tijd ded wgudelige Folck indmede med sahme schieppe som de Udmette heri Landed effter Christi egene Ord Luk. 6,38«. Da Hertuginde Anna døde paa Gammelgaard 1668, bemærker Præsten, at hun var god mod Tandslet Kirke og forærede den Kalk og Disk (se foran). Til Asserballe gav hun et Alterklæde. "Men her til Kiercken (Ketting) gaff hun aldrig inted, hvor vel hun altid søgte her Guds Huus. Doch effter hendis død fik vi ded schønne Tijmeglas och ded herlige Crucifix, som henger paa dend Nørre Sijde«. Ogsaa andre tænkte paa Ketting Kirke og skyndte sig med Hjælpen. Der fandtes $1663 \mathrm{bl}$. a. en sort blomstret Messehagel, som en Præstedatter aff Jylland ved Naffn Anne Olufsdaatter effter de Brandenborger Røffued Kirckerne her udi landed forehrede her til Kiercken. Da der var bortført 2 Sølvkalke med "Commentz eller Dische«, saa gav Præsten af sin fattige Formue en Commentz (som Forvalteren havde givet en Kalk). Da nogle Aar senere Fyrstinden endnu skænkede en Messehagel "med trej diamanter paa (saa kunde man kende den fra Præstedatterens), maa vel de værste Spor af Krigen være forsvundne.

En Hjælper og Velgører kom ogsaa - noget senere - i Oksbøl. Petter Endvald forærede en større forgyldt Kalk og Disk 1695, derefter en rød Fløjels Alterdug og en stor Lysekrone med 8 Arme.

Anno 1669 havde Kirken i Notmark Besøg af Kong Frederik III, hvilket Præsten har optegnet i et gammelt Eksemplar af Kong Frederik II's Bibel, der tidligere laa i Kirken. „A. 1669 
c. 9. Sept. hora 8 var her i Kirken Frederik III og bladede i denne Alterbibel, besaa længe Frederik II's Billede og læste i Davids Salmer, lod oplæse Thomas Stures Epitafium, læste selv alle Sententser paa Bigtstolen, havde og Kalk og Disk i Haanden, som havde været røvet af de allierede, desligeste Hans Fasters (Taters?) Morder-Kniv - - begierede H. Maj. at tage med sig til København en gammel Munke-Alterbog in $8^{\circ}$ paa Latin med Pergamentsblade, Kong Valdemars Lovbog paa Tysk med Munkebogstaver henved 200 Aar gammel«. Endnu bemarker Præsten, at Kongen døde 22 Uger efter. "Han talte meget om den udhugne Død paa mit Epitafium«. Den gamle "MunkeAlterbog" maa Majestæten virkeligt have faaet med; den ligger i Det kgl. Bibliotek.

Hvad det 17. Aarh. ikke fik Bugt med af Brist og Bræk i Kirkerne, maatte det folgende Aarhundrede tage sig af. Men det fik dog desuden sin særlige Opgave, idet Befolkningen efter det stærke Blodtab under Krig og Pest tog til at formere sig omkring 1700. De mange Lofter som af den Grund maatte bygges, skal senere omtales.

I Asserballe skete store Forandringer. Vi læser: "Som denne Kjercke nogle Aar siden haver været saa brøstfældig, at den snart laa neder paa Jorden og siden dend Tid er bragt $i$ god reparation en deel efter Kierckens forsvars ordre 1714, en deel ved Sognepræstens store flid til at bevæge Guds børn og allermest sine egne Venner til medlidenhed, saa bliver her alleniste meldet, at Klokkehuset af Sognepræsten og samtlig Menighed paa deris egen Bekostning er opbygt af ny saa og at en ganske Hvælving i Koret, hvor tilforn var Loft (af Træ?) er blevet bekostet af Sognepræstens Broder Sr. Christian Thomsen, Købmand i Flensborg. Item Nye Messehagel og Alterklæde af samme givet og skænket er". Midt i Aarhundredet udvidedes denne Kirke i Vest og senere i Nord og Syd, saa man nu vanskeligt kan se, hvad der er den oprindelige Bygning.

I Tandslet maatte der en ret stor Restavrering til 1728. "Som Kirkens Tag randt mange Steder igiennem, at folcket 
hid og did ey kunde sidde tørt i Guds Huus, saa er samme og Gud være æred nu saa vel og forstandig blevet giort, at ieg (Præsten) derved glæder mig “.

Omkring 1720-30 var der lidet lysteligt i Notmark Kirke. Loftet i Vaabenhuset var »aldeles øde og borte - mon ikke Brandenborgerne havde brugt det til at varme sig ved? - foraarsagede megen Kulde i Kirken og maatte belægges«. Om Vinteren kunde snart ingen staa bag i Kirken, fordi Loftet der $\dot{i}$ mange Aar havde været daarligt. Formodentligt var det Kaadnere og Tjenestekarle, som stod dernede; men det var dog ogsaa Mennesker. Det blev ikke bedre af, at der i den modsatte Ende af Kirken, i Koret, trængte til at indsættes 40 store Ruder. Et Uheld stødte til et Par Aar senere, idet "det stoere Vindve oven $\mathbf{i}$ det nederste Koer blev moxen ruinered jdet at et $\mathbf{j}$ Kircken indluckte Menniske Brød derigiennem«. Kirkegaarden havde længe staaet uden Lukke, der maatte bygges nye Porte.

Store Arbejder maatte foretages i Nørborg (Tuntoft). Et nyt Kapel byggedes 1786, hvortil Havnbjerg maatte give $100 \mathrm{Rd}$. Det var nødvendigt "til Kirkens bedre rømme«. Om et nyt Orgel, nye Lofter og Taarne skal vi hø̈re senere. Det kostede mange Penge.

I Havnbjerg brugte man 1749 bl. a. 7000 glaserede Tagsten fra Lybæk. Nye Stole sattes 1762.

For at skaffe Plads til hele Sognets Befolkning, mens nye Slægter i voksende Antal mødte frem, udvidede man, som vi har set, enkelte Steder Bygningen udadtil med Sidekapeller o. lign. Asserballe Kirke fik mange Tilbygninger. Men netop her var der dog allerede 1694 et Pulpitur (Tabeltur) inde i Kirken. Ogsaa i Tandslet (og Ulkebøl) har man kendt et Pulpitur i det 17. Aarh. Det Loft, som Karlene stod paa, var nemlig allerede 1709 ganske brøstfældigt. I Havnbjerg var der et Loft med Aarstallene 1674 og 1724. Det gamle Loft i Notmark Kirke, hvor de unge Folk havde deres Stade, var ganske øde 1716 - var altsaa ogsaa gammelt - morkt og alt for nedrigt, langt af Præstens Aasyn og misbrugtes til al Modvillighed, maatte derfor nødvendigt nedbrydes og belejligen med det nye store Loft, 
som Menigheden paa egen Bekostning byggede, kombineres. Af disse Enkeltheder ses det tydeligt, at Folket omkring 1680-1700 sad tæt i Kirkerne paa Als. Trods mange øde Gaarde, der stadigt savnede Beboere, er det klart, at Livets Fylde bredte sig over Landet, mens de hærgende Krige og Hjemsøgelser endnu var i frisk Minde.

Men det er dog egentligt først efter Aar 1700 at TilhørerLofterne breder sig, ogsaa her paa Als. Den Forandring, som ønskedes i Notmark, indtraadte 1723. Et nyt Loft blev bygget paa egen Bekostning af en Del Sognefolk. "Effter at forneffnedle Lofft af største Nødvendighed og Kierlighed til Guds Ord er blefuen bygt«, saa begærer Ejerne at faa Pladserne fordelte. Lidt Selvkærlighed var der nu nok med i danne Offervilje. Allerede 1736 trak det sammen til et Attentat imod dette private Byggeri. Selve Tolvmændene i Sognet truede med at lade Loftet nedbryde igen, da det hindrer Udsigten til Prædikestolen. Man paastaar desuden, at i sin Tid kun tre Mand fik Lov til at bygge sig en Stol, og at Kirken ikke har faaet den ringeste Indtægt af Loftet, men at Ejerne gør en marchandise og sælger eller udlejer Pladserne. Hertug Augustus var paa Tolvmændenes Side. Og da der virkeligt samme Aar tales om et nyt Loft, mens det gamle er flyttet, synes Tolvmandskollegiets Bestræbelser ikke at have været helt forgæves. I 1748 er der stvende nye Lofter, hvilke høyeste Nødvendighed udkrævede for at skaffe Menigheden Rumme«. Endeligt tillod Kongen 1762, at der gaves 1 Rd. af hver Kirke i Fyens Stift bl. a. til en Udbygning eller Kapel paa den nørre Side, da Kirken er for lille. Da fik Præsten den Tanke, at det omstridte og ildesete Pulpitur af 1723, som altsaa eksisterede endnu, skulde flyttes til Kapellet, naturligvis under Ejernes stærke Protest. Hvad enten nu Præstens Forslag vandt Fremgang eller ej, saa er alt dette Byggeri et stærkt Bevis paa, at Folkevæksten i det 18. Aarh. var af en frodig Natur i Notmark Sogn.

Mens Folket tog til, formerede sig ogsaa Pjanket, det altid 
frugtbare Pjank. Biskop Lodberg i Odense, den ærlige danske Mand, sad længe og grundede over et Ord i Egen Kirkes Regnskaber 1725. Han kunde ikke begribe det, om det var aldrig saadan. Da han dog skulde indhente nogle Oplysninger i Sagen, bad han Provsten om Noglen til ogsaa denne Gaade. Provsten svarede: "Dette Ord skal læses, Haberen eller Haure«. Hvorfor saa Provsten i det danske Sogn paa den danske $\emptyset$ skrev Haberen - ja, det er noget, man godt kan falde i Staver over 200 Aar hagefter. Ellers var det i Egen Sogn som i Nahosognene. Et gammelt Pulpitur blev forlænget 1726, formedelst "Stolletrang". To Hvælvinger bag i Kirken blev nedbrudte 1768 og Tolvmandsloftet flyttet tilbage. Et nyt Kapel byggedes 179i. Et Loft var anbragt saaledes, at man for at komme derop maatte benytte en Gang, der var anbragt tværs over Kordøren og gjorde, at Præsten fra Alteret slet ikke kunde se noget Menneske paa Loftet over hele Kirken eller disse Præsten og Alteret. Egen Kirke var i det Indre som et Labyrint.

Omkring $1760 \mathrm{kom}$ en rejsende Præst ind i Nørborg Kirke og saa sig om. Han skrev i sin Bog, at den var ret smuk og rummelig med et skikkeligt Orgelværk og et stort Pulpitur, hvor de fyrstelige Hofbetjente havde haft deres Stole. "Deres Betjeringer og Rang, fortsætter han, staar endnu malede over nogle firkantede Afdelinger, hvori Apostlenes og Evangelisternes Billeder forestilles, saa at det falder lidet latterligt at se Apostlen Jacobus, Hofbereiter, St. Marcus Küchenmeister etc.« (Dyssel).

I Oksbøl rejstes et Pulpitur 1742, ligeledes i Svenstrup; i Ulkebøl og Ketting fik man et 1749.

Som vi har set andre Steder, var ogsaa paa Als Malerpenslen og Farvepotten i stor Virksomhed i det 18. Aarh.

Efter at nye Stole var satte, i Havnbjerg Kirke 1762, kom Mester Jonas Herdal fra Nørborg og viste, hvad hans Pensel formaaede, paa Loft, Stole, Prædikestol og renoverede Alteret, men synes ikke at have gjort godt Arbejde, da Fredrik Ebbesen renoverede Alter og Prædikestol og Tavler i Kirken, samt Loft og 
Døre m. m. med ægte Forgyldning og nogle Oljefarver $1772-$ maaske efter Kunstens Regler. En tredie Maler nævnes 1788: Sr. (Seigneur) Licht Maaler paa Augustenborg.

Mange Kunstnere har været i Arbejde i Svenstrup. Hans Ebbesen B. H. (Billedhugger?) kvitterede 1738 for 6 Rd. "for et Krützefigs, som jeg haver gjort udj Kircken og tuende gamele Billeder reparered, som staar derhos". Man syntes godt om ham og lod ham renovere Alteret 1752. Han kaldes Maler og Billedhugger og malede alle Stole $\mathrm{i}$ Koret 1762. Men 17i \& er det Jonas Heidahl, vel den samme som ovennæunte J. Herdal, der maler og renoverer alt Træværk, Alter og Prædikestol med ægte Guld. Ia Kontrakten med ham var uheldig, kom Peter Ebbesen til at fuldføre Arbejdet 1776, idet han endvidere overstrøg med blaa Oljefarve 10 Fag Loft, marmorerede 1,1 store Bjælker og overstrøg 25 Stole med blaa Oliefarve og Ledestykkerne med brun Oljefarve og forgyldte Himlen over Prædikestolen med ægte Guld og Sølv. Saa havde dette Menneske med sit Blaa og sit Guld sat Præget paa Svenstrup Kirke i den næste Menneskealder.

I Nørborg afgav den derværende Maler Hægerstelt og Schnittger Erich Sederberg 1749 et Tilbud, som vistnok blev antaget, betreff. die in der Kirche an dem Altar, dem Orgelhause mit Zuhehør und der neu erbauten Pulpitur erforderliche Reparation und Ausziehrung an Mahlerei und Schnitgearbeit.

A. Knutzen reparerede Prædikestol og Alter i Tandslet med Maleri og Forgyldning, saasom de saa meget bedrøfvede ud". Men i Slutningen af Aarhundredet gjorde man Akkord med den os velkendte Jonas Herdahl i Nørborg, som efter hans eget Udsagn gik ud paa følgende: 1, solte ich den ganzen Boden mit einer hellen Perlenfarbe und die Balken mit einer dunkelblauen Farbe anmahlen - 2, der Standboden gleichfalls Blau, die Ausfüllung darin aber blau marmoriert - 3, von dem Altar Fuss bis ganz, unten in der Kirche gleichfalls blau - 4, die Kanzel blau und weiss marmoriert - 5 , das alte Altar welches aufgeputzt wird mit allerlei diversen Coulören. Viljen var vist god 
nok; men Mesteren havde sine svage Sider. Præsten skrev en Dag til en af Hertugens Hofraader, at Maleren var blevet alt skyldig i sit Sovekvarter og i Værtshuset og har sneget sig hemmeligt bort. Hans Skrin og Malerredskaber staar endnu i Sakristiet. Sin Vest har han hængt paa Korset. Den hænger der endnu og vil vist raadne op. Viel ist wohl nicht daran verloren. V'iel aber hat Jonas überhaupt nicht zu verlieren.

Samtidigt med Mester Jonas malede Peter Ebbesen der paa Egnen. Vi traf ham allerede i Svenstrup. I Egen maatte han male med blaa Farve 20 Fag Loft og 38 Stole, i Havnbjerg Loft, Stole, Bigtstol, Præste- og Degnestol, Træværket om Alteret m. m., ogsaa Skilderier. Disse to flittige Mænd fra Nørborg har malet hele Als Norreherred blaat i blaat.

I Oksbøl malede dog Sr. Koch fra AErøskøbing. Der var dengang Nalere, som var Seigneur og andre, som ikke var Seigneur.

Ved Aarhundredskiftet $(18 \mathrm{C}, 0)$ havde han travlt i Egen. Allerede 1778 havde man opført seet nyt Kisthuus (?)«. Dorefter kom Amtmand v. Døring og besaa Kirken wegen des bewussten etwaigen Anbaus. Kirkegaarden beplantedes 1810, og det Kapel som nu var indrettet til Sakristi fik nyt glaseret Stentag i Stedet for Bly. Og Farten gik videre. Der levede i Odense en Mand ved Navn J. Hanck, han kaldtes Stiftsbygningskonstruktør. En foretagsom Mand med Fantasi. Han fik den Opgave betroet at ombygge og forskønne det Indre af Kirkerne i Egen og Havnbjerg 1818. Da han fremsendte sine "Grund- og Profiltegninger" haabede han at det vilde "give disse Kirker en Form, der kan være passende til deres Bestemmelse og behagelig for den dannede Kirkegængers Sands for det Skønne og Edle«. Alteret og Prædikestolen er "i en temmelig plump Stiil mens dog ikke anstødendes", kan altsaa blive staaende. Orgelet derimod maa flyttes (skønt det var flyttet, mens Fædrene regerede). Koret frigøres for Stole. Det slet sammensatte Gitterværk, som giver Staderne paa Pulpituret Lighed med Hønsehuse, maa forsvinde. Stolestadernes forreste Ender (Gavlene) mister deres overflodige Zirater, og det hele males graat (ikke mere blaat), 
med mørke Fyldinger. Men Højdepunktet - ikke blot bogstaveligt - er Loftet; det skal helt omkonstrueres. Der indskydes 2de lange Vekselbjælker. Mellem disse Vekselbjælker indsættes faa hvert 2. eller 3. Fag af Bjælkelaget Bræddebuer, som er dobbelt sammenslagne af Brædder der gaar om hverandre, saaledes at Sammenføjningerne af det ene Sæt altid er over Midten af det andet $o$. s. v. Stiftskonstruktøren kom desværre kun til at konstruere paa Papiret.

Det følgende Aar blev Als og ALrø et selvstæendigt Bispedømme og gled dermed ud af Sammenhængen med Fyns Stift. Forresten fortæller C. Knudsen i sine Samlinger (B. III), at før 1809 fandtes der i Egen Kirke langs med Kirkens Hovedgang til begge Sider paa Stolene Opsatser, hvorpaa var malede Billeder af Kirkens gamle Biskopper, Helgener og Helgeninder, disse ret smukke Levninger fra den katolske Tid skal Præsten (Ahlmann) have skaffet bort (?).

Dermed er de store Restavreringer saa smaat begyndt som afslutter vort Tidsrum. Sognepræsten i Havnbjerg H. Mever indherettede 1830: "Den gamle Altertavle, oprettet man ved ikke hvor længe før Reformationen, var allerede da jeg blev Præst i Havnbjerg højst brøstfældig og ormstukket. For nogle Aar siden fandtes den øverste Del (1/3) af Tavlen nedstyrtet paa Alteret og aldeles forslaaet. Man fandt det raadeligt at nedtage Resterne, der var øjensynligt aldeles faldefærdige og vansirende for Kirken. (De kom paa Kirkeloftet). Jeg kan med Sikkerhed tilføje, at Kunsten og den gode Smag ingenlunde have at beklage Tavlens endelige $\Lambda$ fgang. Menighedens Ønske oin at se noget, hvor simpelt det endogsaa maatte være, anbragt til Ajterets Prydelse, er bifaldet af H. K. Højhed Gouvernøren Prins Kristian ved en naadig Inspektion af vore Kirker og Skoler her paa Landet. $H$. K. H. tilbød naadigst at paatage sig at besørge et passende Skilderi og takserede Omkostningerne til ca. 200 Rd." Saadan gik det til, at Havnbjerg Kirke fik en Altertavle af C. W. Eckersberg, det eneste Stykke Arbejde, som denne Mester - mig bekendt - har leveret til sit Hjemlands Kirker. 
Middelalder og Oplysningstid, større Modsætninger findes vel ikke. De mødtes i Havnbjerg Kirke. Længe havde den gamle Altertavle staaet $i$ Koret og lyttet til nye Profetier fra Prædikestolen. Intet forstod dell. Men den anede, at nu maatte den og dens Evangelium dø. Alt er forandret. Guld er ikke mere Guld. De hellige Apostle i dens Sidefløje er ikke mere Apostle. Kun Træ. Noget unævneligt og ubegribeligt gnaver paa dens Væsen, æder i dens Indre. Engang var den paa Samtalefod med Havnbjerg Menighed, den saa gamle og unge flokkevis knæle for sit Ansigt. Nu er det forandret, det er forbi. At dø kan gaa stille af, umærkeligt. Det synes den gamle dog ikke om. Den vælger den dramatiske Vej. En Nat bryder den sammen, lige tværs midt over. En Tredjepart siger Præsten, ja det var nok til at udslukke Livet. Resten opløstes af sig selv. Saa er kun Bisættelsen tilbage, Middelalderens Gravlæggelse. Den kom ikke i en hvælvet Grav som de Præster, der engang havde sunget Latin for den, saa dens Hjerte hoppede. Den kom paa Loftet. "Vi taber ikke noget", sagde Præsten, og han maatte jo vide det.

Hørup Kirke oplevede den almindelige Modemisering 1844. Pladsen ved Alteret tomtes. Det Gitter, som skilte Koret fra Skibet, fjernedes, og det Krucifiks, som hang derpaa, fjernedes og fik sin Plads paa Væggen. Paa Stolperne ved Indgangen til Stolene (Gavlene) var anbragt en Slags Hoveder, som især gjorde det mørkt paa den nordlige Side, de blev bortskaarne uden Barmhjertighed. Gibsloft, koldt og hvidt som Døden, bredte sig over det hele. Alligevel fandt man Kirken, da den var blevet malet meget hyggelig. I 1849 matte den tjene som Krudtmagasin. En ny Restaurering i det Indre fulgte saa 1859 .

Skønt Nørborg Kirke var blevet ikke saa lidt forandret 1857, var den dog nogle Aar senere endnu fuld af Lofter og indelukkede Stole, ogsaa i Koret, saa der var meget mørkt i Rummet. Under Midtskibet var en Begravelse med mange Kister. I en af dem laa en lille Pige særligt godt bevaret. Hun havde en Krans af kunstige Blomster paa Hovedet og ligeledes en 
Krans i Hænderne. Hele Graven blev opfyldt og jævnet. I 1863 forhandlede saa D. G. Monrad som Kirkeminister med Professor Winstrup om Udarbejdelse af Forslag til en indre Restaurering af Kirken; men disse Planer maa vare strandede i 18(i4.

Den samme Winstrup blev taget med paa Raad i Egen 1856 og holdt her virkelig sin Haand over adskilligt gammelt og godt, hvad vi næppe havde tiltænkt ham. Det var Biskoppen Jørgen Hansen, tillige Sognepræst i Egen, som onskede Kirkens Iorskønnelse. Professoren eller Arkitekten svarede, at Fagværket ikke kunde bære Gibsloft, og antog derhos, at Trieloftet malet paa en passende Maade altid vilde vare smukkere end Gibsloft. Orgelets Plads - det stakkels Orgel skulde flyttes igen burde ikke forandres og Pulpituret heller ikke. Saa forstandigt talte Hr. Winstrup. Med en sur Mine giver Biskoppen Dokumentet denne Paategning: "Vidi. Det bliver altsaa ikke andet at gøre end at bede Winstrup om at foreslaa passende Maling af Loftet. Men Altertavlen turde vel vare det mindste, Biakoppens egen Kirke burde forsynes med, naar sagkyndige fraraadede alt andet $\%$.

I Oksbøl lykkedes det derimod at faa det elskede Gibsloft. Hele den indvendige Restavrering kostede op imod $2000 \mathrm{Rd}$. (efter 1853).

Vi ser, at baade nedbrydende og bevarende Kræfter var i Arbejde. For at give Tidsaanden hvad den kan tilkomme, skal her endnu tilføjes en lille Bemærkning vedrørende Havnbjerg Kirke, som findes hos R. Haupt: "Taufstein noben der Kirche im Gebüsch«. Disse faa Ord er som en Lyskaster der i et Par Sekunder afdækker en svunden Tids Ansigt. Nu er den foragtede Døbefont igen paa sin Plads, indtil andre Hænder kaster den ud paany.

Og nu lidt om Kirketaarnene paa Als.

Historien om Havnbjerg er lang. Sr. Johan Thortsen i Sonderborg byggede 1757 et nyt Klokkehus, i Stedet for det afbrækte gamle ganske forfaldne og uanseelige Klocke Huus. Sognemændene slukkede, tro imod gammel Skik, deres Tørst 
med to Tønder $\emptyset l$ hos Kromanden i Lavensby, da Klokkehuset blev rejst. Det havde staaet $3 / 4$ Aarhundrede, da Ønsket om et nyt Taarn $d$. v. s. et rigtigt Kirketaarn begyndte at sætte Sindene i Bevægelse. Det kong. Rentekammer gav 1829 Bevilling til „Opførelsen af et nyt Klokkehuus paa Hagenberg Kirkes Vapenhuus». Licitation afholdtes 1831 efter Overslag og Rids fra Bygningsinspektionen i Slesvig. Taarnet skal stadigt staa over Vaabenhuset og tækkes med Kobberplader. Det gamle Klokkehus forsvinder. Murermester Callesen i Aabenraa, hvis Slægt lever elldnu, gav et Bud paa Arbejdet og fik Rentekammerets Samtykke. Men det er saare vanskeligt at bygge Taarn. Det viste sig, at den stolte Bygning vilde blive 3 Fod lavere end selve Kirken og maatte derfor kasseres. To Aar senere har Rentekammeret modtaget Risse und Anschläge zu einem Thurm von dem Oberbaudirektor Conferenzrat Hansen und dem Bauinspektor Meyer og overladt Valget til den Kong. Overdirektion (Biskop og Amtmand). Den bekendte Arkitekt C. F. Hansen, fra 1784 Landbygmester i Holsten, kom ikke til at bygge Taarnet - desværre. Det havde varet noget af en Tilfredsstillelse at se et Mindesmærke om hans Kunst og Kunnen i Sønderjylland. I Husum kom han til at bygge Byens Kirke. Hvad der kom i Vejen i Havnbjerg ved vi ikke. Men 1834 tillader Kongen, at det hele lægges tilside og det gamle Klokkehus sættes istand. Men Befolkningen vilde ikke slippe saa hurtigt. Man indsendte til Majestæten en Indstilling om et Taarn efter Tegning af Markussen i Mels fra 1828, hvorpaa København imidlertid ikke kunde indlade sig. En Menneskealder gled hen, Fortidens store Navne forsvandt og nye dukkede op. Havnbjerg forlangte igen et Taarn, og nu skulde det være. L. A. Winstrup, den ofte omtalte, levede paa det Tidspunkt (1856) som Stadsbygmester i Flensborg, en meget ringere Mand end Konferensraaden, men dog et Navn. Til ham skrev Overdirektionen, at man frem for de foreliggende Tegninger af Arkitekt Zeltner og Amtsforvalter Gæhler har valgt at lade Taarnet opføre omtrent som ved Sottrup, Rise og andre mellemslesvigske Kirker. Pensioneret Hus- 
foged Grotrian paa Augustenborg har herefter forfattet Overslag og Tegning og er villig til selv at staa for Opførelsen (han kaldes 1845 fyrstelig Bygmester). Der var altsaa Mennesker nok, som vilde hjælpe Havmbjerg til et Kirketaarn. Man gik straks i Lag med at skaffe Materialet tilveje, bl. a. 250,000 "mopser" fra Arnbjerg Teglværk. Det gamle Vaabenhus og Trætaarnet skal nedbrydes og benyttes. Dette Trætaarn lod, siges der, i arkitektonisk Hæslighed lidet tilbage at ønske og var saa svagt, at den store Klokke allerede 1849 maatte nedtages og siden da staa ubrugt. Vel. Men da man begærede af L. A. Winstrup, at han skal føre Overtilsynet, svarede han Biskoppen, at han nok vil gøre det, men at han ingenlunde kan billige Tegningen og selv vil meddele et andet Udkast. Antageligt er dette Udkast blevet benyttet og Foretagendet dermed kronet og kranset. D. 5 . Nov. indviede Biskop J. Hansen Taarnet og talte over de Ord, der var indlagt i Kuppelen, tagne efter 1. Mos. 28, og dermed lystes Velsignelsen over Taarnet. Marineministeren takker samme Biskop, fordi han velvilligt har meddelt Ministeriet, at der paa Als er opført et ualmindeligt højt Taarn, der sandsynligvis vil kunne benyttes som Sømærke. Og da Sognets gamle Præst keg paa Sømærket, kom der en Taare i hans Øje, og han skrev til den høje Overdirektion:

"Som en udmærket skjøn Prydelse er det unægteligt at ansee det herlige og med sit stolte Spir prangende Taarn, med hvilket Havnbjerg Kirke blev i forrige Aar forsynet ved den Høje Overdirektions gunstige og kraftfulde Foranstaltning. En Glædestaare perler ofte i mit gamle Øje ved dets Beskuelse og ved Tanken om den Guds besynderlige Naade, som er forundt mig derved, at jeg har oplevet det Tidspunkt, da Havnbjerg Kirke, hvori jeg er konfirmeret og nu i en ikke ubetydelig Aarrække har forkyndt Ordet, ophøjet til Rang med Alsøes smukkeste Kirker, ja, maaske endog den smukkester. (J. Knudsen). Det er dog dejligt at bygge Taarn. Lad det koste noget. Lad 10 Aar gaa hen med Forberedelser. Lad et Slagtled skrive sine Navne 
i Dødens Bog, mens vi bygger. Det er dog dejligt at bygge Taarn.

I Oksbøl gjaldt det om at holde det Taarn paa Benene, som man havde. Men Kongen bifalder 1734, at det skrobelige Spir nedtages og Taarnet saaledes indrettes "som paa andre Landsbykirker i vore Lande Sjelland og Fyen, især da saadant Spier ej kand være Tegn eller Efterretning for de søefarende i deres Seylatz«. Spiret maa da ikke have været meget højt og nu gik det altsaa alt Kødets Gang. Imidlertid glemte Sognet ikke, hvad der havde været. I 1775 træffer vi en Kontrakt med Entreprenør Seyffert om det nye Taarns Bygning. Saa stod det der igen. Med Stang og Knap. Men henne paa Kirkens Rygning havde der engang staaet et af de slanke og elegante Rytterspir. Hvor var det blevet af? En Stemme - er det Præstens? - hvisker os i Øret: »Dette Taarn blev formedelst Flde og Regnvand sed maxime impulsa alicnius mali spiritus (ved en ond Aands Anfald) afbrudt og aldrig mere opbygt«. Nej, hvem havde vel Mod til det. Det suser endnu saa underligt omkring Oksbøl Kirke. Den onde Aands Bedrift knytter sig ellers til Aaret 1674 .

Ogsaa Hørup Kirke havde over Koret et Spir med Klokke, men tillige et temmelig højt Trætaarn paa Kirkegaarden med de store Klokker. Klokkehuset var meget svagt 1725. Men der var ingen Mester at faa, fordi Kongen byggede paa Slottet, han tog først. Omkring 1730 foreligger der en Beslutning om at nedbryde og af nyt opfore det saaledes som det forrige var "af begriff og størrelse«. Ogsaa det store Rytterspir maatte bringes paa Fode 1752. Da skrev Præsten paa et indlagt Pergament:

Saa lad da storme los de 4 Verdens Vinde

Paa alle Hjørner frem og bruse, de skal finde,

At jeg staar klippefast; thi Herrens V'aretægt

Gjør mig uryggelig og stærk fra Slægt til Slægt.

Den overste Spids faldt dog atter i en Stcrm 1845, og 1872 slog Lynet ned i Spiret. Det siges at have været 24 Alen højt, altsaa et regelret Taarn. 
Skønt man anser det tunge Taarn i Ketting for meget gammelt, maaske samtidigt med selve Kirken, saa opdagede man dog først sent, hvad det gemte i sit Murværk. I 1749 skulde der foretages en Hovedreparation, fordi Taarnet havde faaet "en Bug" paa Vestsiden. Da kom man med Forbavselse efter, at den hele Mur udvendigt kun bestod af en hel Sten og indvendigt kun af en halv, medens dens Indre var fyldt med Natursten og derefter indtil de nederste Bjælker med Sand og Jord, hvorfor Klokkerne maatte nedtages og sættes paa nyt Egetømmer. Taarnet slugte henved 30,000 Rødsten.

Der var baade Taarn og Rytterspir paa Lysabild Kirke. I Aarene 1687-90 samlede man Penge ind til Hjælp til det skrøbelige Spir (vel det store). Den lille Korklokke lod man nedtage 1693, saa som Tømmerværket var forraadnet. Den kom op igen 1705. Men det store Taarn ventede sikkert endnu en Stund paa en grundig Forbedring. Vi gæster Lysabild under et Uvejr d. 23. Febr. 1718. "I de fleste Huse, hører vi, var Folk oppe og bad Gud inderligen om Naade. Det holt ved til Kl. 12 om Naaten. Det slaa gaf paa vort Torn paa Kirken ved den sadvest Side. Traerne laa faldne i skauen det ene ofuer det andet." Kirken var i Fare. Skaden blev naturligvis gjort god igen saa godt det gik. Men Taarn bliver Taarn, det koster Penge. Et grundigt Arbejde "ved Tornene" begyndte 1747 og endnu 1750 var der store L'dgifter til dem begge, men særligt til det ganske brostfældige store Kirkespirs Reparation. Og saa varer det kun godt en halv Snes Aar, da skal Taarnet nedrives og et mindre opbygges, hvortil Kongen bevilger et Bidrag fra Kirkerne i Stiftet. Det nye Taarn, som fuldendtes 1763, var meget lavere. Og om det gamle gaar Sagnet, at det var af saa stor Skønhed, at der efter dets Model skulde bygges et Taarn ved Slesvig Domkirke.

Tandslet Kirkeregnskab anfører en Sum, som er "forbygd paa den ny Kircke spir at igien opsette som var afblest 1627. Et Klokkehus nævnes i 1721. Nogle Mænd tog et Syn over Kirken 1737, da fandt de Taarnet meget vaklende og Klokkehuset skrø- 
beligt. Det maatte der raades Bod paa. Endnu er der Klokkehus og Rytterspir i Tandslet.

Ulkebøl havde 1632 stor Bekostning "med tornett at ferdich giøre som I forgangen Aar bleff af brend formiddelst torden och Liun Jld". Klokkehuset blev 1634 ganske brostfældigt, "udj dend store Storm (med Stormflod vesterpaa) og maatte klædes igien med deller (Planker)«.

Tilsidst maa vi tage en Tur over til Norborg. Her klagede man i Slutningen af det 18. Aarh. over de store Udgifter, man havde haft. Foruden et nyt Orgel og nye Kirkelofter var "tvende nye Kirke Tarne opbygt, hvoraf det sidste kostede 1400-1500 Rd.". Vi maa se at finde ud af, hvordan det hæenger sammen med disse "Tarne«. De kan ikke have været samtidige. Vi ved, at der opfortes et Klokkehus af Egetræ 1755, 40 Alen højt. Men et Lyn vdelagde det allerede 1788 og man maatte til at bygge igen. Det er vel de to Taarne. I 1788 tvivlede man nu om at kunne skaffe Kgetræ, og der foresloges at nojes med et Spir paa Kirkens Gavl. Da kom Hjælpen ganske uventet, idet Enken efter en Kirkeværge viste, hvad der saa ofte er vist, at en enkelt Person kan mere end de mange. Hun lod Klokkehuset opstaa igen og udbad sig til Løn en Begravelse i Kirken. Der ligger hun vel saa. Forhaabentligt uforstyrret, thi hun forlangte Graven tilmuret efter sig, at ingen videre paa dette Sted herefter skal og maa begraves. Men hendes Klokkehus maatte vige for et rigtigt Taarn. Derom har vi en anden samtidig Beretning. I Stedet for at satte et Klokkehus paa Kirkens Gavl fandt man det nemmere og sikrere at bygge Taarnet paa Grundmuren af et Kapel. Her blev det virkelig rejst allerede 1789 og Enkens gode Gerning var da overflødig. I Stedet for maatte Omegnens Kirker gaa i Forskud med Kapital. Sr. Carl Ulrich fra Augustenborg byggede Taarnet med et pynteligt Spir, noget lavere end det forrige (som det plejer at gaa). Men til det forsvundne Taarn eller Klokkehus knytter der sig en Ejendommelighed, som vi lægger Mærke til. Det var, som der udtrykkeligt siges, af Træ, men stod dog 
op ad Muren ved Kirkens Vestgavl, ganske som et almindeligt Kirketaarn. Vi har her altsaa et Eksempel af samme Art som de under Aabenraa Provsti omtalte Kirker i Vis- og Uggelherred. Morsomt er det forøvrigt at læse, hvad R. Haupt skriver: Die Westmauer hat innen 2 Einsprünge als habe da ein Turm geruht - hvad der altsaa i Virkeligheden ogsaa har. Alligevel bliver Spørgsmaalet saa, om der ikke i gammel Tid stod et muret Taarn, hvis Tilværelse helt er glemt.

Vi søger nu ind i Kirkernes Indre for at læse noget Historie ud af de enkelte Stykker Udstyr, saa vidt det ikke allerede er sket i det almindelige Overblik.

Det vigtigste Stykke er Alteret. C. Knudsen fortæller, at der paa det gamle Alter i Notmark Kirke var et dybt Hul, hvori fandtes "en Træskee (skal vel være: Eske) med lidt tyndt Bly og noget rødt Tøj«(Relikvie). En ny Altertavle omtales 1849. Da godkender det Slesv. Holst. Lauenb. Kancelli, at Overinspektør Hornemann paa Augustenborg udleverer den Altertavle, som henstaar paa Slottet i Augustenborg til Pastor Fangel i Notmark og at den opstilles i Kirken. Den skal i sin Tid, efter hvad Overinspektøren har erfaret, være skmnket af Prinsesserne. Notmark Kirke, der var meget smukt restavreret, manglede just en Altertavle. Billedet er en Kopi efter Havnbjerg.

Egen Kirke l:ar nu et Maleri af Storch. Det er et Nadverbillede, og C. Knudsen kalder det en Kopi af det i Sønderborg, om hvilket han fortæller, at det blev fundet paa et Skib fra Holland, der drev i Land i Sønderborg. Farverne er kraftige, men Kunstværdien ikke stor. De udskaarne Figurer, som i sin Tid fyldte Alterets Midtparti (Gud Fader, Kristus og Jomfru Maria) findes stærkt medtagne i Museet i Sønderborg. Fodstykket har i Midten bevaret Billedet af Jomfru Maria i Straalekransen, mindende om italienske Fremstillinger fra Middelalderen. Endnu læses tydeligt: O Maria, mater dei, ora pro nobis - 1515. Dersom denne Tekst var skrevet paa Dansk, var den vel ikke blevet bevaret. Hele Altertavlen er i Baroktiden forsynet med Gavlstykke og Rankeværk. 
Præsten Peter Conradus $(\dagger 1620)$ i Tandslet, beskyldes for at have set for meget gennem Fingrene (nimis lenis judicio frater) med adskillig Løsagtighed, maaske ved Hoffet, derimod var han streng med at ødelægge alt, hvad der stammede fra Katolicismens Tid. Han lod nedbryde de katolske Altre i det sydlige og nordlige Kapel. Den Altertavle, som var »ziirlig malet« 1729 , blev fornyet af J. Jessen omkring 1800 .

Den gamle Tavle i Havubjerg, hvis dramatiske Endeligt er skildret ovén for, kom tilsidst til København. Den havde et Maleri, hvorpaa tilvenstre saas Helvede, tilhøjre Skærsilden, i Midten Kristus paa Domstolen, hos ham hans Moder, som ganske blotter sit Bryst (Pontopp. Ann.).

Lige som i Tandslet nedbrødes i Lysabild et Par Altere omkring 1600. Mon ikke Tilskyndelsen er udgaaet fra Odense? Til Hovedalteret skabtes 1791 en ny Tavle af Bygmester Blashøj og Billedhugger Rudolphsen i Augustenborg. Maler Licht satte, Farver paa; men selve Alterstykket (Nedt. af Korset) maledes af J. Jessen og er en vellykket Kopi efter en af Rubens malet Altertavle i Colmar Kirke, "ganske udmærket" (C. Knudsen). Jes Jessen var rigtignok ikke uden Evner, vi kender udmærkede Portrætter fra hans Haand, men han var heller ikke bange for at give sig i Lag med noget, som laa ud over disse Evner.

Et stolt Syn saa man i Svenstrup. Bag Alteret paa Værgen var at læse alle Danmarks lutherske (se, se!) Kongers Navne med Aarstal (fra Frederik I). Det gamle Alter restavreredes 1680 .

Mester Eckersberg malede Kristus i Getsemane til Kirken i Havnbjerg. Skønt den Slags Malerier ikke havde den første Plads i hans Kunst, ser vi dog nu en Kopi af Billedet baade $i$ Notmark og Ensted.

Jens Bartelsen i Oksbøl gav $10 \mathrm{M}$. til at staffere Alteret $\mathrm{i}$ Sognekirken. Det var ikke mange Penge, men de blev anvendte efter Bestemmelsen 1631. Efter R. Haupt har denne Kirke faaet et nyt Alterbillede 1853, en Kopi efter Jerichau i Kobenhavn.

Den gamle Altertavle i Ulkebøl var fra Begyndelsen af det 
16. Aarh., altsaa lige som den i Egen og adskillige paa Fastlandet fra Middelalderens allersidste Slutning. Udskæringen var fortrinlig, die Bilder sind bei weitem das beste in ihrer Art im Lande (Haupt). Et Skilderi paa Alteret (vel en ny malet Tavle) skaffedes tilveje 1694 for $24 \mathrm{M}$. Det straalede saa længe den gamle Kirke stod.

Alterbilledet i Asserballe er malet 1719 af J. H. Jakobsen, en mig ubekendt Mand. "Slet malet", siger C. Knudsen.

Fra Ketting meddeles 1743: "I dette Aar har Hendes Højfyrst. Durchl. Fru Hertuginden skænket et nyt Alter til vor Kirke. Den betingedes hos Hans Christian Snedker i Hundslev for 12 Rd. Da disse Penge endnu ikke er betalte af Fru Hertuginden og Snedkeren trænger ind paa mig (Kirkeværgen?) og krævede sin Betaling, har jeg indtil videre og indtil omtalte forhaabede Betaling udlagt Pengene af Kirkens Kasse - 36 M.«. Samme Snedker gjorde 1754 eine lehne um den Altar for $27 \mathrm{M}$. Men det ses ikke, at Hertuginden - Ihre Hochf. Durchl. zu schleswig-Holstein-Sonderburg - har opfyldt sit Løfte. Det er den fyrstelige Hofraad Jessen, som hvert Aar reviderer Regnskabet uden at minde om det smertelige Punkt. Men 1755 har den naadige Fyrste (meịn gnäd. Furst und Herr) betalt Kirkens Gæld 220 Rd., aus blosser Gnade. I samme gamle Kirke solgtes 1761 Guldtresserne af den opslidte Messehagel for $9 \mathrm{M}$., desgleichen drey Böhmische Steine for 18 M. - Et gammelt Sidealter med Jomfru Maria i Straalekransen stod i Middelalderen i stor Anseelse (15. Aarh.). Det er paafaldende, saa mange gamle Altertavler der er forsvundne ikke blot paa Als, men i hele Provstiet. Asserballe, Broager, Dybbøl, Hørup, Ketting, Lysabild, Sottrup, Tandslet, Ullerup og Ulkebøl har Altertavler fra det 18. Aarh. Kun et Par af de Altertavler, som endnu er i Brug, stammer fra Middelalderen.

Om Alterrummet er endnu at bemærke, at der flere Steder, bl. a. ogsaa i Sønderborg og Kegnæs, fandtes et Gitterværk, som adskilte Koret fra Skibet. Skønt dette Gitter de to nævnte Steder ikke kan være ældre end fra Hertug Hans' Tid, maa det dog 
antages at det andre Steder var en Levning fra Katolicismens Dage. Flere Gange, f. Eks. i Tandslet 1721, træffer vi paa "Matter i Choret for Communicanterne at sidde paa ved Alteret«. Der var øjensynlig endnu ikke noget Knæfald, og Altergæsterne maatte sidde d. e. knæle paa Maatterne.

Iblandt Prædikestolene var og er der en Del gamle, endog meget gamle. Da Sivert Povlsen i Holm døde 1627, rostes han for at have skænket $100 \mathrm{M}$. til en ny Prædikestol. Den gamle, som maa have været en af Landets ældste, kunde dog bruges endnu. Vi læser, at Hr. Povl i Ulkebøl 1645 begærer "en gammel Predickestoel af Tuntoffte Kircke for sin Svagheds Skyld at hand deraff kunde holde bedestunden«. Og samme Aar har man givet Hr. Anders til Tuntofft for en gammel Prædikestol 6 M. Paa den holdt saa gamle Hr. Povl sine Bedetimer. Men hvor er den blevet af? Vi vilde gerne have set gamle Hr. Povl og den gamle Stol.

Ogsaa i Egen har der været en ældgammel Prædikestol. Den blev nedbrudt 1600 og en ny bestilt hos den kendte Billedskærer Heinr. Ringelingh. Den første han fik færdig blev imidlertid ført til Sønderborg og opsat der. Den næste lavede han saa til Egen for $60 \mathrm{Rd}$.

Naar C. Knudsen paastaar, at der paa Prædikestolen i Tandslet læstes Tallet 1516, er det sikkert en Fejltagelse. Den plattyske Indskrift peger afgjort paa Tiden efter Kirkespaltningen (maaske 15\%6). Der stod i ophøjet Skrift: Gades Wort Bleft van Nu Beth In Ewicheit Tho Ewigen Tidt. Derefter er der indskaaret:: All Wert Pracht Mot Slicht Vorgahn Gots Wort Allen Blivt Ewigh Stan Es. Am. 40. Et næsten ligelydende Vers findes i Gettorf og bag Alteret i Mariekirken i Lybæk. Paa Hjørnerne læses Bogstaverne J. E. S. U. S.

Henrik Holk, Ejer af Rønhave og Ballegaard og overste Sekretær i Kongens Kancelli, skænkede en Prædikestol til Ulkebøl Kirke; ogsaa den er forsvundet. Dens Efterfølger fik sin Plads over Alteret, langt borte fra Menigheden, og man maatte derfor til en senere Præst bygge en ny Stol nede i Kirken. Den- 
ne Stol var uheldig for Tilhørerne, saa at Præsten lod den sænke 3 Kvarter for at de Vollerupper Karle, som stod bagest under Orgelet, kunde se Præsten.

Prædikestolen i Hørup er skænket af Thomas Stures Arvinger 1578. Paa et stort Bræt ved Siden fandtes denne Indskrift: Rope Erheve Dine Stemme Alse ein Bassune o. s. v.

Den nye Stol i Svenstrup er bekostet af Præsteparret og samtlige Sognefolk 1688 for 123 M. Fred. Ebbesen gjorde Arbejdet.

Alle disse Prædikestole havde tyske Indskrifter. Ketting Kirke fik en Prædikestol 1571, i samme enkle Stil.

Ogsaa paa Als har man været tidligt paa Færde med Kirkemusik. Sognekrøniken i Ulkebøl fortæller, at der var et gammelt Orgel af 6 Stemmer, som var skænket af ovenmæunte Junker paa Rønhave. Det er muligt, at dette Orgel saa vel som Prædikestolen var anbragt over Alteret, en Stil, som kendes fra Sydslesvig og andre sydlige Egne. Ulkebøl Kirke har altsaa efter al Sandsynlighed haft Orgel helt fra Midten af det 16. Aarh. og indtil denne Dag. Dog mener C. Knudsen, at det første Orgel stammer fra 1570.

I Nørborg var der stort Gæstebud 1664, anstiftet udj Sekretarii Huus Fyrst. Naade Hertug Hans til Fre, fordi Hans Naade havde foræret et Positiv udj vor Kirke. Enten maa dog Navnet eller Aarstallet være fejl. Et nyt Orgel opsattes 1691 og atter et 1709.

Præsten i Havnbjerg L. Wegerslef forærede et lille Orgelværk til sin Kirke omkring 1780, hvilket senere blev forstørret.

I en Dagbog fra Egen Sogn læses ved Aar 1768: "Den 11. Juni, da vi kom i Kirken, fik vi at see, at Orgelværket var flyttet ned paa Tolvmandsloftet«. Med dette Flytteri kunde man have ventet et Stykke Tid; thi 5 Aar senere havde det gamle Orgel spillet sin sidste Tone, og 12 Bøndervogne knirkede afsted til Stevningnoer for at hente et nyt Værk, som kom fra Flensborg. Søndagen den 30. Juli efter Prædiken begyndte saa Deg- 
nen offentligt at spille derpaa: Frisk op med Instrumenters I.yd.

Orgelbyggere var Elias Wernischij i Arøskøbing (1690), Peter Lorentsen i Nørborg (1702) og Busch i Itzehoe (1769).

Om Kirkeklokker et Par Ord. I et Brev til Biskoppen 1601 protesterede Hertug Hans imod, at Kongen lader Klokkerne undtagen een føre til Danmark. Næste Aar er han dog nødsaget til at give efter. Hvilke Klokker, der skulde nedtages har jeg ikke Rede paa; men virkelig er nogle sendt til Kobenhavn. Ketting Regnskab har 1603 en Udgift for Klokkerne at vdskiffue (udskibe), som kom til København og Ketting Sognemænd blev skyldige til Ulkebøl Kirke, som Provsten Hr. Johan lofued for offueruegnet off deris store Klocke, som wog widere end thennem tilkom at forschicke thil Kopenhaffn oc kom tilhielp att løse Ketting Klocke med, XXI dl.

I Asserballe, Tandslet, Hørup, Ketting, Oksbøl og Ulkøbøl møder vi de smaa Klokker over Koret, som her jævnligt kaldes Marieklokker; den i Hørup er fra 1371. I Hørup, Ketting, Oksbøl, Tandslet og Ulkebøl var de anbragt i et Rytterspir.

Mange Omstøbninger har maattet foretages, ikke alle med Held. Ulkebøl lod sin største Klokke gaa i Støbeformen 1673. Den laa paa en Skude i Sønderborg parat til Sejladsen til Lybæk. Men uventet kom Arendt Cleimamn, en Klokkestøber fra Lybæk til Byen og tilhød at støbe Klokken hjemme. Han arbejdede med 4 Personer i 14 Dage og brugte Mursten, Voks, Fedt, Smør, Ved o. a. m. Fire Aar efter maatte samme Klokke omstøbes i Husum, whvilken Klokke Arendt Cleimann omstøbte her paa Kirkegaarden 1673 oc da handlede mod denne Kirke som en bedrager oc Uret færdig Mand, hvilket dend retfærdige Gud hannem betale!"

I Hørup gik det endnu værre 1805. En Klokkestøber i Flensborg skulde omstøbe Klokken, men forsvandt en Dag uden at efterade sig noget af Værdi. Et Brev fra Fensborg lyder bl. a.: Der geschickte Glokken Giesser Kielstrøm, ein Schwede von Ge- 
burt, richtede seine Flucht warhscheinlich mit einem schwedischen Schiff so schlau ein, dass von seinen Effekten auch nichts nachgelassen ist. Die Kisten worinnen das Metall der Hörupscchen Glokke gewesen, standen leer. Unter den Creditoren gehöre auch ich, indem er zur Anschaffung von Wachs etc. zu der Hörupschen Glokken Form auch mich auf den Beutel klopfte.

Mange Kirker havde Sejerværk (Ketting, Nørborg, Hørup, Lysabild, Ulkebøl). Aldst var det i Ketting (1597). I Nørborg kendte man Sejermagerens Hus 1656. Endnu 1854 bemærker Kirkeinspektøren, at Nørborg Ur burde være den Bygningsgenstand, som har den største Interesse for hele Amtet, efter som al Tidsbestemmelse kun kan gaa ud herfra. Til det paa Menighedens saare Længsel og mindelige Bøn anskaffede Crværk i Ulkebøl bevilgedes $100 \mathrm{Rd}$. (1743). Hans P. Lorentsen, Urmager i Sønderborg, tilfredsstillede den store Længsel med et Srhlaguhr von eben der Grösse, Einrichtung und Tüchtigkeit wie die auf dem Rathhause zu Sonderburg. Hørup Sogn bestilte sit 1784 hos Smeden Nicolaj Nicolajsen i Mommark. Lysabild havde faaet et lige i Forvejen men uden Visere, hvad man dog var ked af.

Inden vi forlader Kirkens Indre for at gaa ud paa Kirkegaarden, kan der gøres et Par Bemærkninger om Ligbegængelse og Ligkapeller. I Svenstrup var det Skik at bære Lig paa Skuldrene; men da Gangen omkring Kirken somme Steder hældede slemt, var der Fare for, at Liget kunde vælte af Baaren, og man gav da Afkald paa den gamle stolte Skik. I Oksbøl havde Præsten B. N. Preen sin Ligkiste staaende paa Kirkeloftet (1761). En Forpagter paa Melsgaard, Peter Enewald, var meget gavmild mod Oksbel Kirke og lod tilsidst bygge et Gravkapel for sig og sin Hustru ved Kirken. Han døde 1697. Ligene af Egteparret var endnu paa $C$. Knudsens Tid ret vel bevarede. De var balsamerede og klædte i hvidt Silketøj. Konen var "mere sammenfalden og saa ilde ud, men havde været smykket med fine hvide Kniplinger og Sølvkniplinger, som var bortødslede i sængde i hendes Kiste«. Selve Kisterne har været overtrukne 
nıed sort Læder og beslaaet med Metalplader. En rig Mands Grav, lige som Gaverne til Kirken var en rig Mands Gaver. I Egen Kirke bisattes 1681 Hertug Frederiks anden Hustru Eleonora. Hun havde bestemt, at der skulde være en Aabning i hen(les Kiste, at hun ikke skulde mangle Luft, hvis hun var skindød.

I Ulkebøl var der $1686^{\circ}$ et Benhus.

Kirkegaardene paa Als bærer vel nu om Dage allevegne Vidne om Øens Frugtbarhed og Blomsterrigdom. Men ikke altid var det saadan. Præsten og Tolvmændene i Notmark skrev til Hertugen 1825: "Nutmarks Kirkegaard ligger ved en alfare Vej og frembyder for den Forbirejsende et modbydeligt Syn, da Uorden og Væmmelse skrækker Øjet tilbage og fornærmer den Ordens- og Skjønheds-Følelse, som bør være og underholdes i ethvert Menneske, ikke at tale om den Spot, som de der have en bedre indrettet Kirkegaard mule os med«. Det var ikke stort bedre i Lysabild. Herfra skrev man 1837: "Længe have vi underskrevne Tolvmænd med billig Harme seet paa, at vor Kirkegaard endnu befinder sig i den usleste Forfatning, medens alle andre her paa Landet under den Højfyrst. Durchlauchtigheds Patronat (Augustenborg-Distriktet) ere blevne planerede, ordentligt anlagte og forsynede med anstændig Indheguing og skjønne Jernporte, og vi tilligemed den fornuftigere Deel af Menigheden have stedse næret det Ønske, at det samme her maatte være Tilfældet, hvor Kirkegaarden deels ved sine høje Banker, dels ved sine store Fordybninger ikke allene vanzirer clen maiestætiske Kirke, men ogsaa ser ud som om den ikke var nogen menneskelig Begravelsesplads« o. s. v. Nogle gamle Træer maa bort, de er for største Delen plantede af de forrige I'ræster, og den nuvær. Sognepræst gør ingen Fordring paa dem. Men de omtalte store Ujævnheder havde vel for en Del deres Grund deri, at Lysabild Kirkegaard dengang endnu bar tydelige Spor af gamle omgivende Volde og Grave, hvis oprindelige Betydning ikke kendes. 
Paa Svenstrup Kirkegaard var anbragt et Bræt paa Kirkemuren (1817) med denne Indskrift:

Til Tanker du indbyder mig

Du stille Sovested!

Her hvor den trætte Landmand sig

Til Hvile lægger ned.

Han Jordens Dagværk fuldendt seer

Og ham er Hvilen sød.

Ej vaagner han til Møjen meer

Og ej til Jordens Nød.

Og naar og vore Been engang

Nedsæinkes her i Muld,

Naar under Klokkelyd og Sang

Man kaster Graven fuld,

Da græder og en kærlig Ven

Her ved vort Hvilested

$\mathrm{Og}$ ofte mindes vi igien

Med hans Sørgmodighed.

Paa Kirkegaardsporten stod der:

De forklarede bor ikke her, dog fredes om Stedet, hvor Støvet nedlagdes.

Skampælen eller Gabestokken med sit tunge Halsjern fandtes vel sagtens allevegne paa den skønne Ø. I Egen og Nørborg var den da engang. C. Knudsen mindes, at Katrine Silke flere Gange straffedes med Halsjern om Søndag Formiddag ved Opgangen til Nørborg Kirke. Længere tilbage er der fortalt fra samme Sogn, at en Forbryder skulde for Tingstokken forst slaa sig paa Munden; der næst skulde han ligge 8 Dage i Fængsel paa Vand og Brød, omsider staa i Halsjernet her ved Kirken og tilsidst gøre aabenlyst Bod, hvilket ogsaa altsammen blev eksekveret paa ham 1728. Omtrent paa samme Tid stod Lorentz Detler med Kone og Søn i Halsjernet ved denne Kirke. Skarns Folk.

\section{Nye Kirker.}

Saa tæt som paa Als har de fyrstelige Slotte og Herregaarde ingensteder ligget i Sønderjylland. Paa disse Gaarde indrettedes mere eller mindre pragtfulde Kapeller til Gurlstjeneste 
for Fyrsten og hans Folk. Slotskirken i Augustenborg blev i Tidens Løb til en Sognekirke, ligesom Slotskirken i Graasten paa Sundevedsiden. Disse Slotskirker kan dog hverken efter deres Oprindelse eller deres Byggeform regnes med til Landsbykirkerne og maa derfor lades ude af Betragtning her.

Tilbage bliver tre nye Sognekirker paa Als, nemlig i Kegnæs, Ketting og Ulkebøl.

Kegnæes Kirke er bygget af Hertug Hans d. y. Am Tage Johannis Baptistæ 1615 lod denne Fyrste opsætte et Dokument vedr. det ny oprettede Sogn. De første Sætninger lyder:

Im Nahmen der Heiligen unzertheilten Dreyfaltigkeit, Amen.

Wir Johannes - Thuen Kund vnd bekennen an diessen offenen Brieffe - Nach dem Wir zue Verbesserung Unser fürstl. Hofhaltung vnd jähl. einkommen, zue diesem Unserm Amste Sondburgh anitzo bey Vnserm Meyerhof uf Kekenis zwey newe Dörfer westerbui vnnd Süederbui genannt angelegt vnd erbauen, auch dabey Gott dem Allmächt. zue ehren vnnd zue befurderund der Unterthanen Seelenheils vnd Sehligkeit ein Newe Kjrche aufrichten lassen vnndt derselben hiemit nach itziger Jahrszeit den Nahmen zue S. Johannes gegeben haben wollen - etc.

Efter C. Knudsen (Samlinger) byggedes der et Vaabenhus, over hvis Indgang en Tavle var anbragt med disse Ord: Anno 1695 ist diesen Seegenhaus durch Hr. Claus Paulsen und Frau Anna Gott zu Ehren der Kirche zur zier und der Gemeinde zum Besten Andenklich verehret. Et Pulpitur opfortes i Pastor Brolunds Tid (1755-67) og der indrettedes Stolestader under Taarnet, "der endnu kaldes Per Kromands Kirke« (Knudsen). Et Træværk adskilte Koret fra Skibet (ligesom i Sønderborg).

Ved Visitatsen 1751 nedskrev Provsten, at Pastor emer. Bøtticher Aaret i Forvejen havde oprettet en Kontrakt med Kirken, hvorefter han havde Lov til at bygge en Begravelse over Jorden (altsaa et Gravkapel) ved Kirkens Nørreside, i hvilken han og hans Hustru og Barn vilde stedes til Hvile. Men Præsten døde før han fik sin Plan udført, og Arvingerne fri- 
toges for alle Forpligtelser. Det er, saa vidt mig bekendt, den eneste Præst i Sønderjylland, der vilde bygge et Gravkapel.

I Ketting stod det engang udbulnende Taarn nu godt, men den ovrige Bygning maatte fornyes. "Anno 1773 d. 12. May Er Ketting Kierke Besigtiget og saaledes Befonden At den ikke kan staa uden at rebereres for Korred Er farligt og ferdig at falde Ned. Derfor er Besludted at Korred med geuelft og de stoer Bue Medt i Kierken skal Nedbrydes og saa setes i lige lini Med den anden Mur som Bliver standen. Dog skal den gamle Mur huerr En allen Hoyer som den $\mathrm{Er}$ og $\mathrm{Ny}$ bielker og sparrer ouer alt saa Bliver den lige høy Med Laudt og tag og Ingen geuelft Men onderskales og Med gebs over alt«.

Det blev en hel ny Kirke, hvortil der brugtes 79,000 store Mursten; den kostede $2595 \mathrm{Rd}$.

Men C. Knudsen har hørt, at den gamle Kirke skal have været langt smukkere og anseligere, af Kamp, med et mindre Spir paa den astre Ende. Den var ikke saa grumme hrøstfældig. "Grunden til dens Nedbrydelse tillægges mest Provstekonen Mad. With; thi da der en Søndag faldt en stor Klump Leer ned ved Siden af hende i Stolen, blev hun herover saa forskrækket, at hun erklærede ikke mere at ville komme i Kirke, førend man fik en ny «. Den ny Bygning var "udvendigt at se til meget tarvelig og simpel og stod indtil for faa Aar siden med sme stygge graa Mure og smaa Ruder af solbrændt Glas med tætte Jorustænger. Hertug Chr. Frederik sagde, at den ikke var saa smuk som hans Hestestald paa Augustenborg". Grosser öder Saalbau har R. Haupt kaldt den. Mens den byggedes holdtes Gudstjenesten under en gammel Eg i Præstens Langbjerg. Kirken var i 1853, 21/8 Aar efter Krigen endnu Krudtmagasin.

Ulkebøl Kirke havde, saa langt tilbage vi kender dens Historie, Tilbøjelighed til mere Udsmykning og større Pragt end almindelige Landsbykirker. Men Alderen tog paa den ogsaa. Igennem hele den forste Halvdel af det 18. Aarh. maatte den stadigt hjælpes. Murene slog Revner, taglam var den. Og da den hørte Provstefruens Tale i Ketting, gik der ogsaa gennem den 
en Bæven, den følte Ve og Værk i alle sine Lemmer. Anno 1787 var det forbi. Som i Nabosognet blev ogsaa her Taarnet staaende. Men selve Kirken nedbrødes og genopbyggedes med en Forlængelse $\bmod$ Øst. Præsten sidder med sin Kirkebog foran sig, og medens Pennen indtegner Navn efter Navn paa smaa nyfødte Mennesker, standser han uvilkaarligt for at fortælle om dette Byggeri. Bedst fortæller dog Kirken selv, som den staar endnu. Et stort og rummeligt Hus er det blevet. Røsten fra Prædikestolen maatte herefter sættes en Tone højere. Med et større Vingefang svævede nu Ordet ud under Tøndehvælvingen og syntes at kræve et mere moderne Tonefald. Stolestaderne har faaet forskellige udskaarne Motiver: Duen med oljebladet, Egern, Planter. Hele Rummet gør et festligt og storladent Indtyyk og viser, at Barok- og Rokokokunsten ogsaa kunde skabe og udstyre et Kirkerum. Det afsluttes i Øst af Alter og Prædikestol, i Vest af det mægtige Orgelprospekt.

Det store Orgel bestiltes straks 1787, men leveredes 1790. Efter Kontrakten med den kong. privil. Orgelbygger Angel i Flensborg skulde det være et Værk paa 25 Stemmer, 3 Cymbalstjerne med 8 Klokker, 5 Vindkasser til Manual, Pedal og Overværk, 2 Klaviaturer, det diatoniske med Elfenben, det cromatiske med Skildpadde. Prisen var (;00 Rd. Den vidtløftige Kontrakt, som bestaar af 20 Punkter, er opsat og skrevet af Christian Rudolph Ebeling, Degn og Organist hersteds. Da han og Slotsorganisten i Augustenborg aftog Orgelet, erklærede de Værket for godt og bevidnede, at $\mathrm{Hr}$. Angel var en Mester i Orgelbyggerkunsten. 